\title{
Implementation of SWOT Analysis in Determining Competitive Strategy On Catering and Conference Services in Hotels
}

\author{
Ari Tihar Marpaung ${ }^{1}$,Aditya Pratomo², and Aries Wicaksono ${ }^{3}$ \\ \{aries.wicaksono@binus.ac.id ${ }^{3}$ \} \\ ${ }^{1}$ Accounting Department, Faculty of Economic \& Communication, Bina Nusantara University, Jakarta, \\ Indonesia \\ ${ }^{2}$ Hotel Management Department, Faculty of Economic \& Communication, Bina Nusantara University, \\ Jakarta, Indonesia \\ ${ }^{3}$ Accounting Department, BINUS Online Learning, Bina Nusantara University, Jakarta, Indonesia
}

\begin{abstract}
The objectives of this research are To find out the internal conditions related to Strengths and Weaknesses and to find out the external conditions related to Opportunities and Threats to Catering and Conference Services, The Ritz-Carlton Jakarta, Pacific Place and to determine the competitive strategy of the SWOT analysis at the Catering and Conference Services, The Ritz-Carlton Jakarta, Pacific Place. The type of this research is descriptive research, while the time horizon that is applied is Cross Sectional Data. Data collection techniques used in this study are observations and interviews. Samples from this study were 18 respondents using purposive sampling. Based on the results of the research Implementation of SWOT Analysis in Determining Competitive Strategies, where divisions that enter cells I, II, and IV can be described as grow and build. Intensive strategies (market penetration, market development, and product development) or integrative strategies (backward integration, forward integration, and horizontal integration) can be the most suitable strategy for divisions within this cell.
\end{abstract}

Keywords: Strategy, SWOT Analysis, Competitive Strategy

\section{Introduction}

The world of tourism is currently growing rapidly and increasing in various parts of the world, one of which is tourism in Indonesia. Indonesian tourism has become an important sector in various fields such as economic, social and cultural. Revenues from this sector are increasing, as evidenced by Indonesia's tourism sector which accounts for around 11-15 percent of GDP (Gross Domestic Product) in 2016 - 2019.

With increasing numbers of foreign tourist arrivals (both tourists and foreign business people) combined with GDP growth and investment growth, there is an increasing demand for hotels and condominiums (which combine the characteristics of apartments and hotels), as well as conference and exhibition venues. What's more, the ASEAN Economic Community (AEC), which began at the end of 2015, implies more intensive trade relations in the ASEAN region which has resulted in greater demand for hotel accommodation.

In the official website of the tourism ministry, it was explained that one of the programs to improve Indonesia's tourism performance as a mainstay of national development continues to be carried out, among others, by organizing the Visit Indonesia program. In order to support the program, the Ministry of Culture and Tourism has designated 13 excellent MICE (Meeting, Incentive, Convention and Exhibition) destinations, namely Jakarta, Yogyakarta, Surabaya, Bali, Balikpapan, Medan, Batam-Bintan, Padang-Bukittinggi, Makassar, Manado, 
Palembang, Mataram, and Bandung. The establishment of 13 flagship MICE destinations has encouraged the holding of hundreds of national and international events in Indonesia each year

Seeing that Jakarta is one of the MICE destinations, it is not surprising that the five-star hoteliers, especially those who are increasingly developing in Jakarta and of course creating innovation and providing the best facilities to attract consumers. The following is a survey of the development of accommodation businesses, especially 5-star hotels during the last 5 years conducted by the Central Bureau of Statistics

Table 1. Accommodation Business Development by Classification Accommodation in Jakarta, $2012-2016$

\begin{tabular}{cccccc}
\hline $\begin{array}{c}\text { Number of Accommodation } \\
\text { Business }\end{array}$ & $\mathbf{2 0 1 2}$ & $\mathbf{2 0 1 3}$ & $\mathbf{2 0 1 4}$ & $\mathbf{2 0 1 5}$ & $\mathbf{2 0 1 6}$ \\
\hline Five Star Hotel & 23 & 26 & 26 & 27 & 29 \\
\hline
\end{tabular}

Likewise with one of the five-star hotels located in the Sudirman area of The RitzCarlton Jakarta, Pacific Place. The Ritz-Carlton, Jakarta Pacific Place, strategically located in the south of Jakarta, precisely on SCBD (Sudirman Central Business District) surrounded by many office buildings making The Ritz-Carlton, Jakarta Pacific Place a very strategic place for business people and companies to hold a meeting. In addition to providing lodging accommodation, the hotel also provides function rooms and ballrooms for meetings, wedding, exhibition, convention and other events

By prioritizing the available facilities such as function rooms, ballrooms and hotel locations in the center of Sudirman business, it only takes 5 minutes from the business or commercial center, so the hotel will be more able to attract visitors, especially business people. Therefore, a competitive strategy is needed that can improve the competitiveness of the hotel and therefore the authors want to conduct research using SWOT Analysis that can identify and analyze external factors related to opportunities and threats and internal factors related to the strengths and weaknesses of the Catering and Conference Services as a reference for determine the competitive strategy of the hotel.

SWOT analysis is a systematic identification of various factors to formulate a company strategy. This analysis is based on logic that can maximize strengths and opportunities, but can simultaneously minimize weaknesses and threats. The strategic decision-making process is always related to the development of the mission, goals, strategies, and company policies. Thus, a strategic planner must analyze the company's strategic factors (strengths, weaknesses, opportunities, and threats) in the current conditions. This is called Situation Analysis. The most popular model for situation analysis is the SWOT Analysis. To be able to establish the company's competitive strategy, the researcher will analyze the SWOT at Catering and Conference Services, The Ritz-Carlton Jakarta, Pacific Place by performing calculations through the External Strategy Factor Matrix (EFAS), Internal Strategy Factor Matrix (IFAS), Matrix IE and SWOT Matrix.

The purpose of this study are: 1). To find out the internal conditions related to Strength and Weakness at Catering and Conference Services, The Ritz-Carlton Jakarta, Pacific Place; 2). To find out external conditions related to Opportunities and Threats at Catering and Conference Services, The Ritz-Carlton Jakarta, Pacific Place; 3). Determine competitive strategies from the results of SWOT analysis at the Catering and Conference Services, The Ritz-Carlton Jakarta, Pacific Place. 


\section{Literature Review}

\section{$2.1 \quad$ Strategy}

According to Ansoff and McDonel (1990) Strategy is a set of rules for decision making to guide the behaviour of an organization. There are four distinct types of rules: standards by which the present and future performance of the company is measured (objectives, targets); rules for the development of relationships with the external environment (product strategy and marketing, or business strategy), rules for establishing relations and internal processes in the organization (organizational concept); and rules by which the company shall conduct its activities in the day-to-day (operational policies).

And other of definition of strategy is Strategy means performing different activities to those performed by rivals or performing the same activities differently (Porter, 1990). Strategy is a set of competitive changes and business approaches that managers perform to achieve the best performance of the company. It is the managerial plan to enhance the organization's position in the market, boost customer satisfaction and achieve performance targets (Thompson \& Strickland III,1995)

Strategy is the theory of the firm on how to compete successfully. It also considers performance as a factor influenced by strategy, as it can be considered that to compete successfully means having a satisfactory performance (Barney,2001).

\subsection{SWOT}

According To Quincy,Lu and Huang (2012) SWOT is a strategic planning method used to evaluate the Strengths, Weaknesses, Opportunities, and Threats involved in a project, organization, or in a business venture. Strengths are aspects or characteristics of the business, or project teams that give it an advantage over others; Weaknesses are aspects or characteristics that place the organization at a disadvantage relative to others; Opportunities are internal and external prospects that can improve organization's performance within the context; Threats are internal and external influencing factors in the environment that could cause trouble for the function or project.

Strengths, weaknesses, opportunities and threats (SWOT) analysis is a device that helps business managers to evaluate the strengths, weaknesses, opportunities and threats involved in any business enterprise, including farms and ranches. A SWOT analysis can help them gain insights into the past and think of possible solutions to existing or potential problems, either for an existing business or for a new venture (USDA, 2008; Nouri et al., 2008). Specifically, SWOT is a basic and candid model that assesses what a business can and cannot do, as well as its potential opportunities and threats. The method of SWOT analysis is to take the information from an environmental analysis and separate it into internal (strengths and weaknesses) and external issues (opportunities and threats). Once this is completed, SWOT analysis determines what may assist the firm in accomplishing its objectives, and what obstacles must be overcome or minimized to achieve the desired results (Singh, 2010). However, completing a SWOT analysis of the farm business is the first step in strategic planning.

\subsection{SWOT Analysis Technique}

According to Irawan (2014: 569) the SWOT analysis techniques used are as follows: 1). Internal analysis consisting of; a). Strength Analysis (Strengths. Each company needs to assess its strengths and weaknesses compared to its competitors. The assessment can be based on 
factors such as technology, financial resources, humanitarian capabilities, marketing power, and pelaggan base. Strengths (strengths) are skills and advantages possessed by competing companies; b). Weaknesses. Is a state of the company in the face of competitors has limitations and disadvantages as well as the ability to control the market, resources and expertise. If people talk about weaknesses in the body of a business unit, what is meant is the limitations or shortcomings in terms of resources, skills and abilities that become serious barriers to the appearance of satisfactory organizational performance. In practice, various limitations and shortcomings of these capabilities can be seen in facilities and infrastructure owned or not owned, low managerial ability, marketing skills that are not in accordance with market demands, products that are not or less requested by users or prospective users and the level of acquisition inadequate benefits. 2) External Analysis consisting of: a). Opportunities Analysis. Every company has resources that differentiate itself from other companies. Opportunities and breakthroughs or certain competitive advantages and some opportunities require a large amount of capital to be utilized. On the other hand, new companies emerge. Marketing opportunities are an area of buyer needs where companies can operate profitably; b). Threat Analysis (Threats). Threats are challenges that are shown or questioned by a tendency or an unfavorable development in an environment that will cause a deterioration in the position of the company. The definition of threat is the opposite of the notion of opportunity. Thus it can be said that threats are environmental factors that do not benefit a business unit. If not addressed, the threat will become a barrier for the business unit concerned both now and in the future. By doing both analyzes, the company is known to conduct a SWOT analysis.

\subsection{Competitive Advantage}

According to Porter (1980: 47) To find out its competitiveness in every strength, Porter advised companies to use one of three strategies, namely differentiation, cost leadership, or focus. The characteristics of the company commonly associated with each strategy. According to Daft (2012: 48) include: 1). Differentiation strategies involve efforts to differentiate a company's products or services from other company's products or services. Companies can also use creative advertising, unique products, quality services, new technologies to produce products that are considered unique. Differentiation strategies can also reduce competition if customers are loyal to the company's brand. Successful differentiation can also reduce the bargaining power of buyers because other products are considered less attractive, which also helps companies to prevent the threat of substitute products. As well as preventing the emergence of new competitors; 2) Cost Leadership Strategy. With this strategy, the company strives to find efficient facilities, reduce costs, and control production rigorously to be more efficient than its competitors. If the company is in a low-cost position, it means that the company can set prices lower than its competitors, but it can still offer relatively high quality and gain considerable profits. Being a low-cost producer is a good strategy for dealing with five competitive forces; 3). Focus Strategy. With this strategy, companies concentrate on regional markets or certain buyer groups. Companies can use differentiation or cost leadership strategies, but the target market is narrow.

An effective way to formulate a strategy is five strengths and a competitive strategy according to Porter. Porter (1985) examines a number of companies and states that businesslevel strategies are the result of five competitive forces within the company. Five Porter Competitive Strengths that exist in the company are: 1). Potential new competitors; 2) Buyer bargaining power; 3 ). Bargaining power of suppliers; 4). Threat of substitute products; 5). Competitors between competitors. 


\section{Methodology}

The type of this research is descriptive research, descriptive research is research aimed at explaining the situation, or a condition that has been explained in the research where the results are stated in the research report. To collect data, in this study assisted with research instruments in the form of a list of questions for interviews. Data collection will be carried out using direct observation in the field and interviews with respondents

In this study the time horizon that is applied is Cross Sectional Data. Where Cross Sectional Data is data collected in certain periods and objects to get the actual situation. The unit of analysis in this study is employees at the Catering and Conference Services of The Ritz-Carlton Jakarta, Pacific Place. The object of this research is the Catering and Conference Services Department, The Ritz-Carlton Jakarta, Pacific Place. The primary data source in this study was obtained by interviewing the Catering and Conference Services to be processed by the researchers themselves. On the other hand, secondary data sources can be obtained through literature studies, such as textbooks, journals, internet media, and data from the Catering and Conference Services. Samples from this study were 18 employees of Catering and Conference Services due to the type of sampling taken, namely purposive sampling in which one day there were 18 experts in the field of Catering and Conference Services. In this study, the researcher took a sampling technique using purposive sampling.

\section{Result}

\section{a. External Strategy Factor Matrix and Internal Strategy Factor matrix}

EFAS matrix is used to find out how much influence the external factors of the company. The EFAS matrix describes the company's external conditions which consist of opportunities and threats calculated based on weight. Next is the EFAS (External Strategic Factor Analysis Summary) matrix which is in this matrix there is a score / rating determination which is done on the basis as follows: Opportunities, rating $=$ very small; $2=$ small; $3=$ big; $4=$ very large. For Threats, giving a score is the opposite of Opportunity. EFAS score results in 2016 are = 3.11 and in $2017=3.20$

EFAS matrix is used to determine how much influence the internal factors of the company. The IFAS matrix describes the external conditions of a company consisting of strengths and weaknesses that are calculated based on weight. The IFAS matrix is a detailed and quantitative description of the Strengths and Weakness variables. In this matrix there is a score / rating determination which is done on the basis as follows: Strength, rating $1=$ very small; 2 = small; 3 = big; 4 = very large. For Weaknesses, giving a score is the opposite of Strength. Whereas to distinguish the weight between the range $0-1$ (total overall weight $=1$ or $100 \%$ ) for each variable based on the importance / not the importance of the criteria have an impact on strategic factors: Weight value 0 indicates not important and weight value 1 indicates very important . IFAS score results in 2016 were $=2.78$ and in $2017=2.86$

\section{b. Internal and External Matrix}

The internal - external matrix is prepared based on IFAS and EFAS values. This matrix is the initial model for obtaining a competitive strategy. IFAS values for 2016 and 2017 are between $2.00-3.00$, so in the matrix the position is in the average position, and the EFAS value between $3.00-4.00$, then in the position matrix is high. With these considerations meeting between IFAS and EFAS scores directs the position of the company's condition to implement strategies to grow and develop. 
The following is the Internal-External Matrix at the Catering and Conference Services, The Ritz-Carlton Jakarta, Pacific Place:

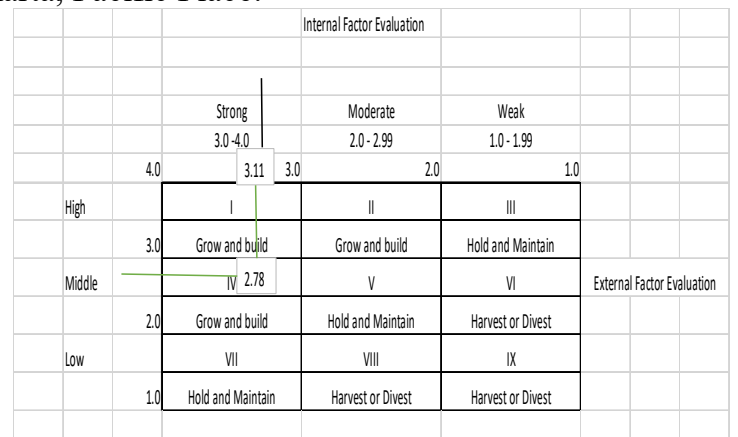

Fig.1. 2016 Matrix IE

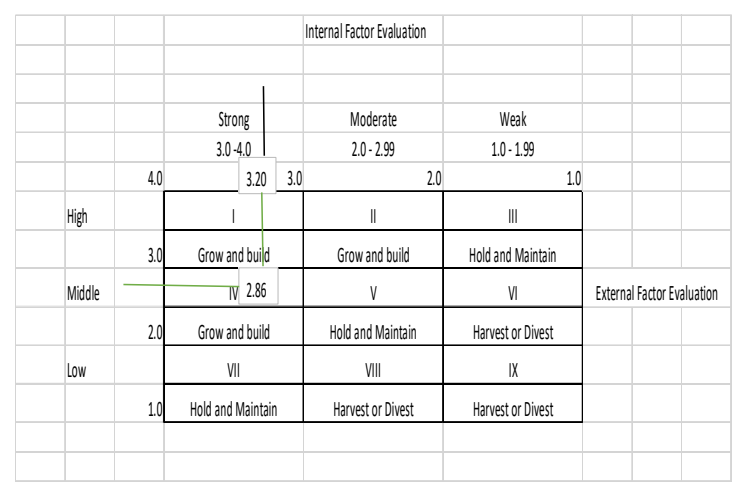

Fig.2. 2017 Matrix IE

\section{c. SWOT Matrix}

Based on the information that has been obtained and has passed the production process, the strategy factor (IFAS / EFAS) can be described as follows: 1). SO strategies (Strengths and Opportunities). This strategy is based on using all the power to take advantage of the opportunities that exist so that they have competitive advantages when compared to similar companies. Like: a). Create an official account to promote events that will be held and promote the venue owned by the hotel; b). Search for information about events that will be held in Jakarta and establish cooperation with companies that will hold these events if the event has the potential to be held at The Ritz-Carlton Jakarta, Pacific Place. And do not forget to collaborate with the organizers who usually handle MICE events, so they can get references; c). Maintain relationships with consumers. Can be done in the following ways: By phone, Sales call and By E-mail; d). Giving rewards to event organizers; e). Prepare and carry out regular promotions directly which can attract the attention of event organizers to want to use hotel facilities, announce special events, offer promos using credit cards; f). Participating in exhibitions related to MICE such as: Wedding Exhibition. 2). ST Strategy (Strength and Threats). This strategy uses the strength of the company to overcome threats. Like: a). Make and offer more competitive and attractive MICE packages; b). Providing a guarantee of security to guests; c). Planning for employee promotion and planning to provide appropriate rewards to employees; d). Determination of competitive prices in accordance with the 
intended target market; e). Establish good cooperation with the press; f). Establish cooperation with online travel agents. 3). WO (Weakness and Opportunities) strategies. This strategy is applied based on the utilization of existing opportunities by minimizing existing weaknesses. Like: a). Providing after-sales services and in particular guaranteeing that all complaints from customers are taken seriously and discussed by each department; b). Rejuvenation of existing equipment and equipment so as to minimize existing defects, and complete the regular event needs according to guest requests; c). Do telemarketing actively to new companies that allow customers to become hotels. 4). WT Strategy (Weakness and Threats). This strategy is based on activities that are defensive and try to minimize existing weaknesses and avoid threats. Like: a). Make temporary room divides for the crew to rest in the Ballroom area; b). Regular renovation planning; c). Facilitate loading access to the 8th floor (given clear directions and supervised); d). Adding signage to the loading area; e). Adding signage for the restroom ballroom area on the 2nd floor; f). Host a meal with several clients who have long been partners with The Ritz-Carlton Jakarta Hotel, Pacific Place; g). Visit each competitor's hotel to get the latest information about new products or promotions carried out; h). Observe with details about issues related to competition (location, price, services offered regularly-quarterly or more often if necessary).

\section{Conclusion}

The use of SWOT analysis plays an important role in determining competitive strategies. In order to know the strengths, weaknesses, opportunities, and threats that the company has; Based on the results of the SWOT analysis which is then calculated in the External Internal Matrix and results in the existence of the company's position in cell IV, namely Grow and Build. Divisions that are included in cells I, II and IV can be described as grow and build. Intensive strategies (market penetration, market development, and product development) or integrative strategies (backward integration, forward integration, and horizontal integration) can be the most suitable strategy for divisions within this cell. And after finding several strategies through this SWOT Matrix, a strategy will be determined that can be used as a competitive strategy for Catering and Conference Services, The Ritz-Carlton Jakarta, Pacific Place.

From the explanation and conclusions above, there are some suggestions that can be taken into consideration to establish a competitive strategy for Catering and Conference Services, The Ritz-Carlton Jakarta, Pacific Place. Advice for the Company: 1). In connection with the results of the EFAS and IFAS Matrix which have increased from 2016 to 2017, it is recommended that the Catering and Conference Services maintain the strengths and maximize the opportunities obtained. And it is recommended to make new innovations such as thematic pop-up restaurant thematic updates held; 2). After identifying what was at the Catering and Conference Services, The Ritz-Carlton Jakarta Pacific Place through a SWOT analysis, it was concluded that for now is to implement the SO strategy (Strength - Opportunities). This SO (Strength - Opportunities) strategy is carried out to harness the power of the company to capture the opportunities that the company has. Using targeted promotional media is media promotion with internet networks because promotional media with internet networks are very appropriate to be used in the modern era, consumers can access their requests easily and flexibly because they can be done anywhere and anytime for example by making an official account via Facebook, Instagram, and so forth. Then also foster good relationships with customers, give rewards to event organizers such as cakes or souvenirs, attend exhibition events that can support Catering and Conference Services; 3). The above is in line with the 
proposed strategy through an external internal matrix that is intensive strategy. Where one of the intensive strategies is Market Penetration Strategy, where this strategy is implemented to promote - sales promotion. Suggestions for researchers: This study only uses EFAS, IFAS, IE, and SWOT Matrix analysis only so that the next research should use other analytical tools such as SPACE Matrix, BCG Matrix, and Matrix Grand Strategy, in analyzing strategy formulation; Further research that should be carried out is research on the level of visitor satisfaction and competitiveness of the Catering and Conference Services; For further research should conduct more in-depth, comprehensive research and a wider range of objects.

\section{References}

[1] Ansoff, H., Mcdonnel, E. 1990. Implanting strategic management. New Jersey: Prentice-Hall, ISBN 01-3451-808-X.

[2] Barney, J. Firm resource and sustained competitive advantage. Journal of Management, Vol. 17, Iss. 1, pp. 99-120. ISSN 0149-2063.

[3] Daft,Richard L.2012. Management $12^{\text {th }}$ edition. Cengage Learning. 978-1305393462

[4] Irawan, Muhammad R.N.2014. Analisis SWOT untuk Menentukan Strategi Pengembangan Tabungan Harmoni Plus Pada BPR Nusamba Brondong Kantor Kas Lamongan, Jurnal Eksbis, 9 (2), 568 - 574,

[5] Nouri J, Karbassi AR, Mirkia S.2008. Environmental management of coastal regions in the Caspian Sea. Int. J. Environ. Sci. Tech., 5(1): 43-52. Riston

[6] Piercy, N. and Giles, W.1989, "Making SWOT analysis work", Journal of Marketing Intelligence \& Planning, Vol. 7 Nos 5/6, pp. 5-7.

[7] Pickton, D.W. and Wright, S.1998, Whats SWOT in strategic analysis?, Strategic Change, Vol. 7, pp. 101-9.

[8] PORTER, M.1980. Competitive strategy: Techniques for analyzing industries and competitors. New York: Free Press, ISBN 00-2925-360-8.

[9] PORTER, M. 1990.What is strategy? Harvard Business Review., Vol. 74, Iss. 6, pp. 61-78. ISSN 0017-8012.

[10] Porter, M.1985. Competitive advantage: Creating and sustaining competitive performance. New York: Free Press, ISBN 00-2925-0900-0

[11] Quincy, R.,Lu,S. and Huang,CC..2012. SWOT Analysis Rising Capacity of your Organization.Huamin Research Center.2-3

[12] Singh ,N.2010. SWOT Analysis - A Useful Tool For Community Vision A concept paper of central Himalayan village. Res., 2(9): 16-18

[13] Thompson, A.A. and Strickland A.J.1995. Strategic management: Concepts and cases. 8th ed. Homewood/Illinois: Irwin, ISBN 00-7231-499-0.

[14] Valentin, E.K. 2001, SWOT analysis from a resource-based view, Journal of Marketing Theory and Practice, Vol. 9 No. 2, pp. 54-69. 